\title{
PRODUCTIVITY, MACHINERY AND SKILLS IN A SAMPLE OF BRITISH AND GERMAN MANUFACTURING PLANTS
}

\author{
Results of a Pilot Inquiry
}

\author{
by A. DALY, D. M. W. N. HITCHENS and K. MAGNER*
}

On the basis of interviews with management and factory floor employees at 45 matched fims in Britain and West Germany, this article examines the roles of machinery and workforce skills in explaining comparative productivity pertormance. The average age of British machinery was not very different from that found in German plants, but it was less technically advanced, was subject to more frequent breakdowns and breakdowns took longer to correct. Productivity was higher in Germany in each of our matched product groups and the importance of skills at all levels was apparent.

\section{Introduction}

This paper is based essentially on some three dozen interviews carried out mainly in matched manufacturing plants in Britain and Germany in 1983-4. The plants were in the metal-working trades, and selected as producers of relatively simple products; the plants were of small to medium size, with generally between fiffy and five hundred employees. The central object of the study, in brief, was to cast light on how preseni-day productivity is affected by differences in the type of machinery used and by differences in the skills and qualifications of the workforce on the factory floor; was it, for example, in processes using advanced technology that Britain was deficient and, if so, in what ways?

By way of background, it is worth recalling recent comparisons of the results of Censuses of Production in Britain and Germany. These indicated that by the mid-1970s German output per employee in manufacturing as a whole was about 50 per cent higher than in Britain, and higher still in mechanical engineering and vehicle production (in the region of 80 per cen:; these differentials have remained more or less unchanged since then. ${ }^{(i)}$ There have been many earlier comparisons of individual British and foreign planis.(2) Taken separately, such case

*The third author is at the Technical Universily, Berlin, and a consultant at the National Institute.

(1)A. D. Smith, D.M.W.N. Hitchens and S. W. Davies, international Industrial Productivity, Cambridge University Press, 1982, p.63, gave comparisons for 1976. Changes in output per employee have been very similar in the two countries since then if we take the period as a whole -including the 'catching-up' in productivity in the last two years in Britain. Relative productivity in the two countries in 1983 was thus much as it was in 1976 (though the UK's relative position had been slightly lower in 1980).

(2)For some Anglo-German comparisons, see: NEDO, Gauge and Tool Sector Working Party, Toolmaking: A Comparison of UK and West German Companies (NEDO, 1981); A. Sorge and M. Warner'Manpower training, manufacturing organisations and workplace-based relations in Great Britain and West Germany', British Joumal of Industrial Relations, 1980; A. Sorce. G. Hartmann, M. Warner and I. Nicholas, Microelectronics and Manpower in Manufaciuring (Science Centre, Beriin, 1983). The Anglo-American Council on Productivity was responsible for some fifty sets of comparisons with the United States in the early 1950s; see especially those referred to below, p.59, footnote (1). studies have been too limited to be regarded as fully representative; yet, taken as a whole and together with the statistics based on the Censuses, it seems inescapable that there is in fact a wide productivity gap between the countries-and one that deserves intensive investigation.

Even in the plants that we selected as producing relatively simple and ostensibly similar products in the two countries, a considerable variety of product specifications and processes was encountered; a fair range of efficiencies was also apparent even within each country. This was of course not unexpected, and it was recognised from the outset that a larger sample might uitimately prove necessary to reach definitive conclusions. With limited resources we were thus content to treat this as a 'feasibility study'.

Our inquiries in fact met with wide interest. No doubt this was related to two puzzling aspects of British and German industry which had become fairly widely known from previous investigations. The first is that the stock of machinery in Britain is not in any obvious way out of date; the postal survey of the metal-working industries by Metalworking Production in 1982 showed, for example, that 24 per cent of all machine tools in British plants has been installed in the past five years, compared with only 15 per cent shown by a similar German survey for 1980, and 13 per cent by a similar US survey for 1983. (3) Those postal surveys did not achieve high response-rates (roughly a quarter in each country) and it is clearly worth attempting to obtain supplementary evidence, with the help of direct interviews, on ages of machinen. If it confirms that our machinery is no older than Germany's, it would make it even more important to know why our productivity record is no better.

The second aspect, much publicised in the past two years in relation to the Government's plans for

(3) See the companion paper, prepared as part of the present inquiry. which examined the resulis of recent large-scale postal inquiries in the stock of machinery in these three countries. National Institute Discussion Paper no. 78, 1984. 
youth training, is that a much greater proportion of the German workforce is trained to craftsman standard: someihing like two-thirds have passed qualifying examinations ait the level, for example, of a trained fitter (similar to our City and Guilds part II examinations) in a wide range of occupations, compared with well under a third of the workforce in Britain. (1) Can it be that British productivity would be significantly improved if the typical worker were a trained and qualified person as in Germany?

The selection of firms to be compared is described in the immediately following section, logether with the products they made and the average productivity difference between the two countries. This is followed by three sections dealing, respectively, with the quality of machinery, the quality of manpower and the quality of raw materials. The implications are discussed in a final section.

\section{The design of the inquiry}

\section{A selected sample}

The crucial decision in the present inquiry was to focus the sample on matched, simple, products. By choosing the sample in this way we hoped to reduce the diversity of ancillary factors affecting productivity elicited in many earlier comparisons; in turn, this might be expected to yield more trustworthy results on the central aspects of interest here (the effects of typical differences in machinery and skills on productivity). A restriction in the range of variation is particularly important here given the need to limit the size of sample on grounds of cost.

We accordingly chose simple matched products in the two countries, such as coil springs, rather than complex products such as laundry machines or internal combustion engines. This would permit an easier understanding of the efficiency factors at work on the faclory floor. One of the crucial questions surrounding training policy today is whether it is sufficient to provide training for engineers, technicians and the few others that are at 'the tip of the iceberg', or whether there are substantial benefits to be obtained by extending training-at very great cosi-to the massive numbers below that level, as is done in Germany. The role of the few staff members in the design, drawing and marketing departments is not of course unimportant in explaining the aggregate gap in productivity; but in the manufacture of simple-as compared with complex - products, the roles of production economies on the shopfloor, and the efficiency of operators, are likely to be of greater im-

(1)S. J. Prais, Vocational qualifications of the labour force in Britain and Germany', National Institute Economic Review, no. 98, November 1981; and S. J. Prais and K. Wagner, 'Some practical aspects of human capital investment: training standards in five occupations in Britain and Germany', National Institute Economic Review, no.105. August 1983. portance and more apparent to the external observer.

Another reason for choosing simple producis is that it reduces the problem of quality variations, and makes easier the measurement of productivity in physical terms (rather than value in national currencies converted at some rate of exchange).

We might have focused more narrowly still by looking, not at matched simple products, but at matched manufaciuring processes in the two countries, such as the turning of metal on automatic lathes; or perhaps even more narrowly, by looking at turnings out of suitably-alloyed steel bars within a limited diameter-range; or yet further, we might have specified the precise type of machine. But there are disadvantages in going too far down that path. The more closely we define the process in terms of machines and materials, the more will its efficiency be pre-determined by technical factors; and the less likely we are to discover differences in output rates and in manning requirements. Efficiency very often lies in choosing the right machines and the right materials to make a particular product. Our decision to base the sample on matched products (rather than on matched processes) thus left open the possibility that we might examine the efficiency of different processes and of different machinery in the manufacture of the same product.

In this way, the range of relevant comparisons has been widened. On the other hand, by confining the sample to products matched as far as possible in the two countries, we have implicitly narrowed the range of relevanit experience, for the following reason. While it is obviously important for the entrepreneur to choose the right machines, the right materials and the right personnel, it is often more important to choose the right product for manufacture. The best mix of products to be manufactured in one country is obviously not necessarily the best for another; in the extreme case, there may not be any matched products at all in two countries; or, if there are any matched products, they may not be typical of each country's production as a whole. For example, if the German workforce is indeed so much more greatly endowed with vocational skills than Britain, as indicated by the statistics quoted above, we would expect a greater specialisation in Germany on skillintensive products; and simple, run-of-the-mill products may hardly be made there at all. One might therefore expect difficulties in finding products that are both 'simple' and 'matched' in the two countries; in any event, a degree of mis-matching is probably inevitable in any inquiry of this sort.

By the same argument, any general tendencies in the nature of observed mis-matches may cast important light on the underlying skill-endowments. For example, a comparison by Parkinson at the end 
of the 1970 s of $8-9$ firms each in Britain and Germany, all of which manufactured machine tools, confirmed that German machines rended to be more specialised to meet individual customers' needs; while British machines tended to be of a more standard type. (1) Customers were happy to pay higher prices for German machines because they met their particular needs with less subsequent expendiure on in-house tooling, and because of their greater technical proficiency, and so on. The need to improve the technical quality of products in advanced industrial countries has become increasingly necessary, as Pakkinson put it, because, 'suppliers from developing countries have entered the market, supplying relatively standard products with lower manufacturing costs'. One reason put forward as to why British machines lagged in product development was that British purchasers of machine tools (in con. trast to German purchasers) lacked the technical sophisticarion to evaluate ideas for new machine lools, and contribute to their development'.

Differences in the general level of technical expertise, whether manifest at the supplier or purchaser and, may therefore influence differences in the specification of the products typically produced in each country.

\section{The choice of products and firms}

The present inquiry was based on the metal-working trades because of their very clear reliance on both machinery and skills; we were also influenced by the parallel postal surveys in these trades. The choice of firms was confined initially to Southern England and the Berlin area to minimise interviewers' travel time and costs; in order to find matched products in the parner country, firms further afield were subsequently approached. In Gemany, again to minimise travel costs, Stuttgart was taken as a second centre for the latter purpose.

Classified trade directories for Berlin provided the initial basis for the selection of mosi of the products to be examined. Because of Berlin's somewhat special circumstances - the greater distance to the main centres of the country's population and industry-the full range of Germany's manufactures is of course not to be found there. Berlin is also exceptional in having a higher proportion of immigrants, and the labour force is somewhat less skilled on average than in the rest of Germany. Nevertheless, a fair range of products is manufactured there in smalland medium-sized firms, and the difference in

(1)S. T. Parkinson, New Product Development in Engineering. A Comparison of the British and West German Machine Tool industries (Cambridge, 1984), passim, especially pp.1, 84. For earlier views see A. Daly and D. T. Jones, 'The machine tool industry in Britain, Germany and the United States'. National Institute Economic Peview, no. 92, May 1980. average skill levels between it and Britain is adequately great for the purposes of this inquiry. We matched the following products: screws and nuts, small coil and leaf springs, cutting drills (i.e. drill bits of various sorts), hydraulic valves, and motor parts (the products are not described more precisely here to avoid breach of confidentality). Most firms produced other products besides those selected for comparison; some produced so wide a range, and in such small batches, that it was better to regard them as general jobbing engineers. Other firms visited could not be satistactorily matched within the limits of the present inquiry; as they were all in metal-working, they nevertheless contributed to the general lessons.

The quality of servicing demanded and supplied in the iwo countries is a matter of concern to users of advanced machinery in both countries. In the later stages of the inquiry we therefore visited a dozen suppliers of machine tools; (2) these had inevitably acquired much experience in the course of aftersales service of the state of technical expertise of their customers. Some were domestic manufacturers, others were distributors of foreign machines or agents, and some fulfilled both functions.

In total, 45 firms were visited, of which three quarters were manufacturers and a quarter were machine lool suppliers and service agents; table 1 shows the distribution of the firms amongsi main product groups. ${ }^{(3)}$ Table 2 shows the distribution of the sizes of the manufacturing firms in our sample in each country compared with national totals of these trades as derived from Censuses of Production. Trade directories (which formed the starting point of our sample) tend to be more comprehensive on larger firms, and it is not surprising that our samples in both countries are over-represented by larger firms; nevertheless, we achieved a fair spread of sizes in both countries. The German sample contained rather more small firms than the British sample.

We approached the firms by letter foliowed by a telephone call. This was done in a series of rounds, alternating between the two countries, to achieve samples as closely matched in product specification as possible; many firms that appeared from the trade directories to be making the same product were found, on closer questioning (on dimensions, etc.), not to be comparable. Approximately half of those

\footnotetext{
(2) We visited nine suppliers in Britain and four suppliers in Berlin; in addition, five suppliers in West Germany (i.e. apart from Berlin) responded in writing.

(3) in addition, three firms were visited by one of us on the US East coast, taking advantage of a journey organised for another purpose. One each of these firms fell into the first three product groups in table 1. This sample is, of course, too small to permit generalisations about the US, but, taken together with the visits to similar producers in Germany, it reinforces our conclusions on the problems faced by British manufacturers in competition with advanced industrial countries. The views of these US firms will be footnoted where relevant.
} 
Table 1. Wumber of fims visited, by type of product

\begin{tabular}{lcc}
\hline Manufacturing firms & Britain & $\begin{array}{c}\text { West } \\
\text { Germany }\end{array}$ \\
\hline Screws and nuts & 4 & 2 \\
Springs & 1 & 4 \\
Drill bits & 2 & 3 \\
Hydraulic valves & 2 & 2 \\
Motor parts & 2 & 2 \\
Jobbing engineers & 1 & 4 \\
Unmaiched(a) & 4 & 0 \\
\hline Total manufacturing & 16 & $16^{(b)}$ \\
\hline Machinery suppliers & 9 & $4(0)$ \\
\hline Total & 25 & 20
\end{tabular}

(a) Metal-working firms with products that may be matched in Germany in any extension to this inquiry.

(b) Allows for one firm that had a department for screws and a department for springs.

(c) A further five suppliers in West Germany responded in writing.

approached who were in comparable trades agreed to our visiting them. The proportion was similar in both couniries, and was similar for manufacturers and distributors. There was no obvious characteristic distinguishing those who were 'too busy' to see us; but we suspect that those co-operating were of above-average efficiency. This seemed clearer in Britain where many participants expressed strong interest in being told what in due course would be learnt from our German visits.

The majority of our visits were conducted by two of us. The more helpful were those where one interviewer came from each country; about half our visits

Table 2. Distribution(a) of shizes of manufacturing plants in the sample(b) and in the population (plants with over 20 ermployess)

Per ceni

\begin{tabular}{lrcccc}
\hline & \multicolumn{2}{c}{ Britain } & & \multicolumn{2}{c}{ West Germany } \\
\cline { 2 - 3 } \cline { 5 - 6 } $\begin{array}{l}\text { Size } \\
\text { (employees) }\end{array}$ & Sample & $\begin{array}{c}\text { Population } \\
(1980)^{(0)}\end{array}$ & Sample & $\begin{array}{c}\text { Population } \\
(1979)^{(c)}\end{array}$ \\
\hline $20-49$ & 6 & 50 & 19 & 40 \\
$50-99$ & 19 & 22 & 31 & 24 \\
$100-199$ & 19 & 13 & 13 & 16 \\
$200-499$ & 31 & 9 & & 24 & 12 \\
500 and over & 24 & 6 & 13 & 7 \\
\hline
\end{tabular}

Sources: UK: Census of Production 1980: Summary Tables (HMSO. 1983). table 6. W. Germany: Produzierendes Genverbe: Betriebe, Beschäftigie und Umsatz im Bergbau und im Verarbeitenden Gewerbe nach Beschäftigten-grossen Klassen, 1979, Reihe 4.1.2. (Statistisches Bundesamt, Wiesbaden, 1980), table 1.

(a) Percentage distribution: totals may not sum to 100 per cent because of rounding.

(b) Excluding machine tool suppliers

(c) SIC 31 and 32 .

(d) Sypronummer 30 and 32 to manufacturing firms were of this kind. For the sake of economy, other visits involved only one of us. Each interview lasted approximately two hours. Usually we interviewed the plant manager (in smaller firms he would be the managing director), and later questioned on the shop-floor, according to circumstances, the foreman, quality controller, maintenance personnel and setter. (1)

\section{Products and productivity}

The specifications of products made by six pairs of firms were sufficiently similar to warrant a simple comparison of labour productivity; the products were: screws, springs, two varieties of hydrualic valves and two varieties of drill bits. The calculations were based on actual (not 'standard') outputs of machines per unit of time, that is, including downtime for tool-setting and changing, material feeding, etc.; depending on how the production process was laid out, and on how records were kept, we sometimes took only an important single part of the production sequence, in others a series of operations, and in yet others the total number of completed products. The ouiputs were related to the numbers directly employed.

In all six comparisons the German firms showed higher labour productivity, varying from a mere 10 per cent to as much as a 130 per cent advantage. The average differential was 63 per cent (a sampling error of 9 percentage points attaches to this estimate). This is close to the figures derived from the Censuses of Production (which, as mentioned, yield differentials of about 50 per cent for all manufacturing and about 80 per cent for metal-working trades). We could discern no relation between the individual productivity differentials and any obvious characteristics of the products (such as their complexily); we attribute the variation in differentials partly to the inherent variability of efficiencies within each country, and partly to imperfections in our measurements.

Several aspects deserve comment. First, in embarking on an inquiry with the present design we were quite prepared to find that only a small part of the total productivity differential between the two countries would be evident at the shop-floor level, especially when looking at simple products; as mentioned, much of the aggregate difference between the countries might be evident only in complex products where, for example, better production design would lead to several operations being carried out simutaneously, or better maketing would lead to longer runs of standardised varieties. While these

(1)The questionnaire was developed in the course of the first few interviews, and acted as a broad quide to the main topics covered subsequently. A copy of the questionnaire, together with a summary of some illustrative interviews, are available on application to NIESR. 
and similar factors undoubtedly have their part to play, it nevertheiess seems remarkable that differences in productivity of such magnitude should emerge at the level of shop-floor productivity in these relatively simple products.

One must not however forget the importance of international competitive pressures. If producers in advanced countries of such simple products are to stay in business at the higher wage levels that have evolved there, they can only do so if their productivity in those products is correspondingly high. We were frequently told both in Britain and Germany of pressures from producers in developing countries who were now producing standard varieties, and able to supply bulk quantities at low prices; established producers in advanced countries were forced either to leave the trade, or to shift towards specialised products requiring greater skills. In both countries some firms were well advanced in modifying their product range, and others were straggling. Too often amongst British firms we found an air of complacency, and even of despondency; one director suggesled his business was unlikely to lasi more than fifteen years 'by which time 1 will have retired'. At another firm-an old-established family firm-the owner seemed unaware of the existence of appropriate new technology (computer numerically controlled machine tools). "We are not interested in productivity here', he said; faster and more up-todate machines, 'present no special advantage and there is usually more to go wrong'. Moreover, he noted, 'the laster the machines work, the sooner the job is compleled and the more setting that will be required'. While not wishing to over-generalise from such remarks, it has to be said that we did not come across similar views in Germany.

A second aspect to be noted in relation to our simplified measures of productivity is that they are based on directlabour only; but it must be added-on the basis of earlier studies - that indirect labour has generally been found lower in other countries than here;(1) our simplified measures are therefore unlikely to be misleading in any serious way.

Thirdly, when examining the products made in the two countries to see whether they adequately 'matched', we discerned a tendency for the German products to be technically more advanced and of a higher quality. For example, in matching screws, we were obliged to take a rather special iype that was produced in both countries; the more standard types

(1) See the NEDO report on Toolmaking and the paper by Sorge and Warner (op. cit.), which noted fewer managerial staff in Germany. Similar findings in comparisons with the Netherlands, Sweden and Japan appear in the reports for NEDO by the Process Plant EDC, The Challenge from Abroad (1982), and the Iron and Steel Sector Working Party, A Hard Look at Steel (1982). To keep our intervew short we did not ask about indirect labour. that are still made in Britain-and which we had selected intially-were no longer produced in Germany because of competition from the Far East. A metal pressing that we received from Germany could not be matched by the British company that we approached because of its complexity (they hoped to be able to produce this type in the future). In matching the hydraulic valve taken from the main part of the British range, we noticed that the German range encompassed a broader and more specialist set of products. (2)

Finally, it needs to be emphasised that for the products compared above the sizes of batches were broadly similar in the wo countries. Whilst we heard much of greater standardisation and longer runs in Germany (e.g., 'A German carmaker would design one spring for which its British competiors would need four kinds'), for the particular products compared here this was not the case. This is not to say that stancardisation is unimportant in general: on the contrary, what we were told on our visits was fully in accord with what has often been said in Britain on these matters - the need to eliminate 'dual working' to metric and imperial stendards; the need for careful design from the outset to incorporate standard units; and the benefits that in consequence ensue from longer runs. (3) However, the present comparisons seem to show that, even when batches of comparable size are made in the iwo countries, there is still a fundamental difference in productivity.

\section{The gualizy of machinery}

Observations on our sample of firms indicated that differences in machinery between the two countries need to be considered under several heads: (i) the number of machines per employee (or, looked at reciprocally, manning levels per machine); (ii) the use of ancillary feeding devices; (iii) normal ouiput rates or running speeds of machines; (iv) ages of machines, taken as an indicator of how modern they are; $(v)$ the use of advanced technology in machinery bought recently; (vi) use of imported machinery; (vii) rate of breakdown, and causes of breakdowns. For the sake of succintness, we shall give first under each head any general inferences that we drew, zollowed by a number of illustralions to add concreteness. The limited size of our sample needs to be kept in mind as one reason why a clear tendency-one way or the other-might not have been discemed under all heads.

(2) Our US visits yielded a similar impression: the drill bits manufactured there were designed to be of higher precision; and the screws made there were similarly designed for local specialist application.

(3) See Sir F. Wamer, Standards and Specification in the Engineering Indusiries (NEDO London, 1977): and the sequel Progress on the Warner Report (NEDO, 1980), which indicates that progress has been unsatisfactory. 


\section{Manning levels}

In conformity with industry-wide statistics on the rise of output per employee in Brilain in the past three years, logether with a decline in total employment, our British sample gave the impression that manning levels on the shop-floor had generally been reduced in recent years; but there was much variability, with some operations carrying on much as betore and others showing drastic reductions in manning. For example, in one plant an operator had previously looked after two automatic multi-spindle lathes, and this had recently been increased to 3-4 lathes; gains of this rype were often related to better feeding devices (larger hoppers or coil holders). This process of demanning appeared to be continuing.

There was considerable variability in the combination of operators, selters and setter-operators employed to run a group of machines in the kind of semi-automated manufacturing processes that we saw. To some extent this reflected requirements posed by cumulative minor differences in machine type, tooling, tolerances and product finish; and it made it difficuli to draw any clear general conclusion on differences bewween the two countries on manning. Where similar machines with similar tools were used, our impression was of no great difference on average in direct, nomal manning between the two countries. In earlier studies, lower manning levels in Germany have been observed.(1)

\section{Feeding devices}

Nevertheless, if was still true that Britsh rather than German plants provided examples where indirect labour, or labour for feeding of materials to the machine, seemed to be unnecessarily employed. In the production of a small motor part, individual components were being hand-fed to the machine, though the batches were large enough to warrant an automatic feeding device; we were told that plans to mechanise this process were in hand. in another British plant the hand-polishing of brass castings was to be mechanised, so that the component was brought to the polishing mops on a turntable instead of by hand; in the corresponding German plant that change had aiready taken place. In the production of screws, the British factory used wire coils of a quarter ton, while the German factory was changing to coilholders taking three times that weight. The larger coil-holders were seen also in other German plants.

(1)The NEDO toomaking comparisons (op.cit., p. 12) suggest that 20 toolmaking machines would typically be manned by 12 skilled men in Germany and by 15 in the $U K$ corresponding to a 20 per cent advantage for Germany. See also the example of cigarette manufacture noted by S. J. Prais with the collaboration of A. Daly, D. Jones and $K$. Wagner, Producivity and industrial Structure, Cambridge University Press, 1981, p. 104.
They reduced not only the frequency of coil changes, but enabled a 'ghost shift' to be operated in some cases; in others, the machines were allowed to run beyond the end of the normal shift, with only minimal supervision, until the raw material feed was exhausted.

\section{Punning speeds}

Normal running speeds of machines were generally not very different in the two countries, but occasionally some differences were observed in favour of Germany. A cold-heading machine used in the production of screws ran about 20 per cent faster in Germany than the corresponding machine in Britain, and the German spring-coiling machine was about 50 per cent faster. In a related case involving the blanking and forming of a pressed metal electrical component from strip, the German power press ran at the same speed as the one in England, but tooling had been 'doubled up' in Germany to yield twice the rate of output. Machine setting generally seemed to take much the same time in both countries.

\section{Age of machinery}

The typical ages of machinery employed varied according to product, but for similar products in our sample much the same age of machinery was found in both countries. For example, in the production of screws more than half the machines in both countries were over ten years old, while in the production of springs more than half in both countries were under that age. It will be remembered that earlier postal surveys of the metal-working industries suggested that machines in Britain were significantly younger than in Germany; our present finding may be said to agree to the following not unimportant extent-ihere was no indication that British industry is deficient because its machinery is of an older vintage than that in Germany.

Two possible reasons may be mentioned-though they are hardly more than speculations - as to why we did not find British machines in our sample to be younger: (a) we were comparing a selection of matched products, and it is possible that these were not typical of production as a whole in respect of the age of machinery; (b) the majority of our German firms were situated in Berlin where there are special tax incentives to purchase new machinery (after three years usage in Berin, some of it makes its way to other parts of West Germany without losing those tax benefits); firms in Berlin may therefore have newer machines than in the rest of Germany. However, the sample of firms that we interviewed in the Stutigart area was too small to enable us to detect any significant age difference with Berlin. 


\section{Numerical control}

In any event, as said, British plants had at least as many recently bought machines as German plants: but were they as advanced technically? Judging by the use of numerically conirolled (NC) machine tools, the answer seems conclusively to be No.(1) In the plants that we visifed which were manutacturing two types of drill bits, ${ }^{(2)}$ we found no NC machinery in Bhitain, but they were being used in the corresponding German plans. Two Eritish plants thought this yoe of machinery could be economically justified only on two shirts; since they were on single shifts, they had decided not to buy. In a number of Geman plants that we visited they were content to run them on single shits. Another British plant was about to purchase such a machine, having put of a decision for many years lo see how others got on; even now, a relatively simple type had been bought because they did not wish 10 go in at the 'deep end'. We formed the impression that there was more technical skill among the decision makers in the German plants, and they were able to work on a lower risk premium, that is, they could see a pay back over a longer period. British plants oflen seemed not to appreciate the full potential of the new technology.

Taking our sample as a whole: of the sixteen German fims visted, fheen were using NC machines; while of the sixteen British firms visited, only seven had done so. This is the more surprising in that our German sample of firms consisted, on the whole, of slightly smaller firms than the British sample (table 2). It shows-very much more clearly than anicipated-that, though British machinery is at least as new as German, it is much less technically sophisticated. We were particularly impressed by the way even very small Geman plants-with only a dozen employees working in hardly more than a converted garage-would include an NC machine in their complement.

Our comparison of matched plants may well yield a more accurate picture of the relative state of applied technology in the two countries than yielded by the earlier general postal surveys which, of course, cover the varied mix of products produced in each country. Nevertheless, il must not be assumed that the proportions of plants with NC machinery shown by our small sample apply nationally in either country; as explained, we are fairly sure there was a

'WWe have throughout used the term ' $N C$ ' to cover both numerically controlled machines operated by punched tape, and the latest generation of computer numerically controlled machines (CNC). The majority of the machines we saw were the more recent CNC machines.

(2)The NC machines were used directly in the production of the three products mentioned, and not simply in making tools for the general machinery used in their plants. tendency for the better plants in both countries to agree to an interviem, and the national propontions are likely to be lower. Nevertheless the proportion of firms approached who agreed to be interviewed was much the same in both countries, and the blases are to some extent likely to be similar. ${ }^{(3)}$

\section{Imported machinery}

We took note of the country of manutacture of $\mathrm{NC}$ machines, and asked generaly about the use of imported machinery. International specialisation in the production of machinery-based on the possibility of longer runs and consequenty lower costs and lower prices-has progressed rapidy, and even countries that are large exporters of machinery find it necessary today also to impont machinery of other types. Nevertheless, as we were told, purchasers of machinery everywhere prefer to buy locally whenever possible, because of easier repairs and the availability of spares. ${ }^{(4)}$

Most of the NC machines that we saw in Germany were made there (although often incorporating controls made in Japan) and the remainder were Swiss, Austrian or Japanese; in Britain, the majority of installed NC machines were Japanese and the remainder were British, Swiss and ltalian.

With regard to machinery imports in general, our sampled firms confimed what is now fairly well known about the relative strengths of the various countries which produce machinery. If anyihing, we found that the trends delineated in the Finniston report in 1980 on the engineering industries had become clearer still. (5) In Britain, thirteen of the sixteen firms visited used predominanty imponted machines; the other three firms, which used predominantly British machinery, were using old-established lypes of machines, though some had been

(3) Some other reasons may be footnoted as to why our sample might show much higher proportions of NC machines than to be expected on the basis of previous surveys. First, our survey was carried out at a later date, and incorporated the recent increase in sales of NC machinery (one of the German engineers we spoke to thought the rise had been very rapid in Germany in the past two years). Secondly, our sampled products are perhaps of a kind more suited to NC machinery. Thirdly, earlier statistics generally refer to the percentage of machines that are $\mathrm{NC}$, rather than to the percentage of plants which own an NC machine (inevitably a much higher figure). A comparative survey specifically directed to the use of NC machinery in Britain and Germany was carried out in 1981 by $A$. Thwaites (University of Newcastle) and Professor J. Ewers (Berlin Technical University); we are grateful to them for telling us of their advance results indicating a significantly higher usage of NC machinery in Germany. On the basis of our limited sample we would not wish to go beyond a qualitative conclusion of that type; though, as made clear in the text above, our particular sample brought that conclusion home to us very forcibly.

(4)This was true also of firms we saw in the United States.

(5) Engineering Our Future: Report of the Committee of inquiry into the Engineering Profession (Chairman, Sir Montague Finniston), HMSO 1980 (Cmnd 7794). Between 1965 and 1982 the British share of world exports almost halved to 7 per cent, while that of Germany fell less sharply from 31 to 26 per cent. 
reconditioned and uprated. (1) Many firms expressed an innate preference for British machines, but ofien had little option except to buy abroad: where apparently suitable British machines were available, they were often technologically backward, performed less well (e.g. less accurate, more liable to go wrong) and, we were told, were uncompetitively priced for their quality compared with foreign makes. There were of course exceptions (recent British CNC machines were mentioned) but that was the general, and unfortunately familiar, message.(2)

All the German firms visited used predominantly German machinery, but among their standard machines were also to be found some of Swiss, Austrian, French, Swedish and Italian manufacture. On being questioned, they said that they did not purchase British machinery either because there was nothing suitable avallable, or because they had previously encountered difficulties.

For example, one firm experienced difficulties in obtaining spare parts for a standard British drilling lathe which was only three years old. Another firm had experienced so many difficulties in obtaining spares for well-known makes of British machines that it decided it would be cheaper to sell them; delays were so severe that those machines were somelimes idle for months. ${ }^{(3)}$

One of the lessons we draw from all this is that attempts made, or supported, by the British government to limin imports of machinery are likely to injure the competitiveness of the British metal-working industry. ti is irue that British machinery producers gain some respite from these measures but the interests of the many users of machines would be sacrificed to the interests of the few producers. ${ }^{(4)}$

(1)The postal survey found only 15 per cent of installed machinery to be imported, whereas our interview survey based on machines in use suggested a very much higher proportion. Part of the reason must be because we were not concerned with machines standing idle, but only with those in use; our sample of products also involved fairly large batchwork, with the attendant need to make use of modern automated machinery which, as explained, tends more often to be imported. Import siatistics indicate that imports in 1981-3 have risen to account for some 40 per cent of all home purchases (Business Statistics Office, Business Mionitor, $\mathrm{PQ} 3321$ ).

12The demise of the British machine tool industry has been the subject of much study and much concern. See, for example, A. Daly and D. T. Jones, op. cit.

(3):f the machines had been built to metric rather than imperial standards repairs might have been effected sooner using German-made parts. The three American companies visited were adamant about repair difficulties in other than American machine tools. The American screw factory would not buy British or any foreign make because of anticipated problems in oblaining spare parts; the spring manufacturer drew attention to the poor productivity of a British coiling machine; the third firm had experienced problems with the elecirics on the only British machine they owned. On the other hand, we were told of (but were unable to visit) a competing screw producer who used old British machines, and found them highly acceptable- but these machines are no longer produced (they were sturdy simple machines originally produced in the First World War to make armaments; the company closed about a decade ago) (4) Since 1982 the Japanese have 'voluntarily' agreed to 'restrain' their sales to Britain of advanced machinery-CNC lathes and machining centres; this agreement was further extended at the time of this writing (Financial Times, 16 November 1984).

\section{Machine breakdowns}

Breakdowns of machinery were reported to us as being a more serious problem in our British than in our German sample of firms; breakdowns in Britain were particularly serious in advanced machinery. In both countries firms often faced teething problems following the introduction of new machinery, but the problems continued to iester in Britain. For example, a British manufacturer of hydraulic valves had faced continuous problems of breakdowns with its NC machinery since installation; one machine had worked for only a quarter of the time since it had been installed. At another British firm making cutting tools, long-standing problems had occurred as a result of dust and heat affecting the microelectronic circuitry. In a further example, eleven machine shitis had been lost by a British screw manufaclurer on iwo important pieces of equipment because the breakdowns could not be attended to by local personnel, but had to be referred back to the machine manufacturers. Breakdowns are of course an ever-present risk; but the point of these examples is that in Germany we were told only of 'teething problems' with new machinery and never of continuous or long-standing problems. The problem of breakdowns in British industry has been a subjeci of serious concern in other studies (referred to below; p. 57, footnote (1), and is closely related to the skills of the production and maintenance workforce, to which we now turn.

\section{The gualiv of manpower}

The greater extent of vocational training in Germany is well known, and in general terms needs no emphasis in the present study; as explained, our interest here was to understand in practice at what levels differences in training affect productivity, and particularly how benefits to be derived from the "new technology' are affected. Within our sample as a whole, about a half of those working on the shop floor in Germany had an apprenticeship-iype qualification compared with a quarter in Britain. This was combined with larger pay differentials in Germany beween skilled and semi-skilled workers. In addition, the pay of German skilled workers tended to be related to their experience according to an accepted scale, while British skilled workers were more often all paid at the same rate. ${ }^{(5)}$

It will be convenient to summarise what we learnt about the technical quality of manpower from our interviews at four levels: (i) foremen and above;

(5)This is in line with the findings of the NEDO toolmaking study. The West Germans achieved more effecive earnings differentials for key employees and hence beiter man motivation'. op. cit. p. vili. 
(ii) maintenance; (iii) other skilled members of the workforce; and (iv) unskilled labour.

\section{Foreman and supervisory skills}

The clearest differences were at the foreman level. In fourieen of the sixteen British firms we visited the production foremen (as distinct from maintenance foremen) had acquired their position purely as a result of experience on the shop-floor, without formal qualifications; in only two cases had they served an apprenticeship. In contrast, German production foremen in all sixteen firms had passed examinations as craftsmen; thirteen had also acquired the higher certificate of Meister (master craftsman), and the remaining three had undergone additional training towards that qualification but had not yei passed their tests.

The course leading to the Meister qualification is intended to enable the foreman to carry out not only routine setting and maintenance of machines, but also to be proficient in staff supervision and work organisation; in addition, it should equip him to carry out machine repairs though, if the repair is a heavy one, he may call in engineering assistance.

Above the Meisier-level a German firm usually employs suitably qualified technicians, and production managers who are typically graduate engineers. All the senior staft that we saw in the German factories were qualified engineers (except in one instance, where he was a qualified technician); in Britain, as Lawrence and others have noted previously, such positions are usually heid by those with a sales or financial background, or by persons who had learnt on the job. (1) This was true of most of the British firms we visited.

This difference in technological qualification has become ever more important because, as we were lold at several inierviews, non-engineers are less receptive to technological innovation; their lack of technical understanding leads to delays in installing technologically complex equipment because they are afraid to 'chance their arm'. For example, a British maintenance foreman told us he could not persuade his management to buy electronic equipment which would reduce their heavy repair costs. because-so he thought-ihey did not understand the technical potential of the equipment; the management were primarily salesmen and were suspicious that the equipment manufacturers were 'irying to pull a fast one'.(2)

The role of the Meister in organising production, in conjunction with the engineer where necessary, was

(1)Lawrence, Managers and Management in West Germany, Croom Helm, 1980 .

(2)A similar point was made by A. Sorge and M. Warner (op.cil.) in relation to decisions associated with the introduction of CNC tools. coherently expressed by a plant manager in Stutigart as follows. "Three-quarters of all improvements in productivity are achieved through ensuring an ade. quate documentation of exact machine-settings; ensuring that all parts are available and are of the right dimensions; that all drawings and measuring devices are available; that all involved know how to do their jobs; that the product-design is appropriate; that the manufacturing and operation sheets are well prepared before work begins, and that no corrections will be necessary as production proceeds. This clear work method has to take place within a clean factory, with clean machines and in an atmosphere of order and discipline. These are the responsibilities of the Meister and engineer; if unforeseen interruptions take place, these men are sufficiently well trained to know how to analyse the problem and act accordingly.'

All this may seem unexceptionable. But in a British factory things are different. In view of the limited technical training of foremen, there is a greater division of responsibilities-with maintenance men, production controllers, quality controllers, all working more or less in parallel to the foreman. Those directly involved in production typically have little more than informal training on the job, and those with formal technical training are in service functions available to the whole plant, such as maintenance, installation or toolmaking. This organisational pattern is consistent with the relative scarcity of trained persons in Britain, and should not merely be explained in terms of general 'cultural' preferences. The lower technical competence of those directly responsible for production has consequences for productivity, as we learnt.

\section{Maintenance}

Breakdowns of machinery, especially of modern machinery, seemed from our interviews to be a much more serious problem in Britain. 'When the machines were running', we were told by one German company which had plants in both countries, 'output was the same; but when a machine broke down in Britain, there was nobody to repair in'. That no doubt was an exaggeration, but it gives the dismal flavour of what was contirmed in other interviews. We were told by a service engineer in Brilain that machines here were 'abysmally abused'; maintenance procedures were inadequately followed; machines were no cleaned of swarf; they were used for purposes for which they were not built (for example, cutting hardened steel on a machine intended for soft metal); when they break down there is frequently no in-house ability to carry out a repair, or even to diagnose the fault. The ability to use diagnostic tapes on NC machinery varied greatly. One NC machine tool manufaciurer had analysed their repair problems, and found that 70 per 
cent should have been dealt with by users themselves if they had employed properly skilled itters. ${ }^{(1)}$

In addition, breakdown in the UK took three or four times longer to repair than in Germany, said one German machine supplier, 'because of delays caused by British rules on demarcation, teatime, hometime and the dirt of the machines'. Unnecessary delays of this kind were also mentioned by several British firms.

Breakdowns were not mentioned as a significant problem on our German visits; nor were there any problems in relation to routine maintenance (the role of the operator in maintenance is considered below). We also did not observe in Germany the related problem of poorly-maintained mechanical feeding devices that we had seen in Britain.

\section{Other skilled personnel}

There was considerable variation in the proportion of skilled workers among the firms in our sample. The difference varied according to the type of product: for example, in jobbing engineering, where there were many 'one offs' or very small batches, both countries had similar and high proportions of skilled persons; where there were larger batches of precision work, such as in the production of drill bits, the Germans had a much higher skilled proportion.

In interpreting the contrast in the proportions who are skilled, it has to be remembered that in Germany the term 'skilled' (Fachmann) has the connotation of 'formally qualified' whereas in England it more often means 'long-experienced'. Our figures relate, as far as was practicable, in both countries to those who have completed an apprenticeship; but in neither country is the distinction entrely rigid in practice. (2) A person doing a job which requires an extended period of on-the-job training may be described as skilled in Britain, even if he has not completed an apprenticeship. This is rare in Germany, where he will be described more often as semi-skilled. The real

\footnotetext{
'1thn a similar vein the British 'Think Tank' had noted in 1975: 'despite the fact that British manufacturers employ $50-70$ per cent more plant maintenance personnel than their Continental competitors, on identical equipment mechanical breakdowns result in the loss of about twice as many production hours in the United Kingdom as on the Continent'. More recently ACARD has noted with concern that the iniroduction of advanced manufacturing technology was hindered by a shortage of maintenance personnel with the requisite diagnostic skills: the complexity of most new manufacturing technologies and related products called for a level of expertise which they had not previously needed' (ACARD. New Opportunities in Manufacturing. The Management of Technology, 1983 , p. 41). The problems of kraining multi-skilled maintenance men in the context of British demarcation lines amongst traditional craft-skills are considered in a reoort by Peter Senker et al. for the Engineering Industry Training Board, Maintenance Skils in the Engineering industry: The Influence of Technological Change (EITB, 1981 , especially Chapter 7).

(2)It proved difficult in the course of our interviews to press these distinctions further; but in any fuller inquiry we would propose splitting the sample so that half are interviewed more closely on
} this aspect. difference in skill levels is likely to be greater than that indicated by the above figures, despite our precautions to ensure comparability.

Aggregate statistics based on population surveys indicate higher proportions of skilled persons in Germany (about two thirds of all employees) than found here. The main reason is probably that we did not cover draughtsmen, salesmen and others away from direct production-and these will more often be qualified (another reason perhaps is that our sampled products on the whole may have involved production in larger batches than in manufacturing as a whole, with consequent greater scope for unskilled repetitive work).

Would it be easy to remedy our deficiencies by adult retraining? Comparative experience on iniroductory courses for NC machines illustrates the difficulties to be expected as a result of past lower levels of training in this country. (3) The use of NC machines is of course relatively new in both countries and, with the constant development of new facilities on these machines, suppliers find it useful to provide courses on special teatures of their machines relating to programming, electrical and mechanical maintenance, and general operation. These courses are run by instructors with similar levels of qualification in both countries (usually HNDs or HNCs in Britain, qualified technicians in Germany). In Germany the setter, chargehand or Meister usually attends, all of whom hold a craftsman's certificate as a minimum qualification.

In Britain, we were told, the courses offered are very basic but the average person attending was not very receptive to them. For example, a 'programmer needs some understanding of trigonometry; some firms would send their "technical man", but he would be without mathematical skills'. As a result there was often a fear of 'interfering' with the machine by those who had attended the course, and an inability to recognise faults; this made it more difficult for an appropriate engineer to be sent when a repair was necessary. 'The upshot of this', we were told by one British manufacturer of NC machines, 'is that almost half the machines sold in Britain are not used as they might be, because their full capacity is not understood?.

In Germany problems of this kind were hardly mentioned; with negligible exceptions participants were capable of following the courses. This difference in technical competence manifested itself again in requests for after-sales service. Depending on the in house skills availabie, users in Germany were able to underiake repairs themselves, or were (3)The findings in this and the following two paragraphs are based
on interviews with senior managers and training staff at machine tool manufacturers and distributors in Britain and Germany. 
capable of diagnosing faults when equipment broke down; this enabled the appropriate engineer to be sent at once to the firm. Teething problems were caused by improper programming and improper toolchanging in both countries; in Germany these difficulties were usually overcome within the warranty period, but in Britain there was a need for suppliers to continue 'to hold hands' with the client after that period.

\section{Unskilled labour}

it is clear from the foregoing that in manufacturing plants producing comparable products, Germany has a greater proportion of skilled personnel; and that their ievel of skills is probably of a more uniformly high level. But as might be expected, in routine tasks much unskilled labour continues to be employed. If appears that even those who are unskilled are expected to work to higher standards, perhaps partly as a result of the influence of the greater proportion of qualified personnel on the factory floor.

This was illustrated by the way German machine operators were responsible for cleaning 'their own' machines, often on Friday afternoons in a special two-hour period at the end of the week's work. This practice was virtually unheard of in Britain, The German view was that this improved productivity in a number of ways, all fairly obvious: (a) cleaning prevented a build-up of swart-excessive swarf by itself induces breakdowns and loss of production (as mentioned, build-up of swarf is commonplace at British plants); (b) the process of cleaning leads to early discovery of minor faults ("the loose screw'), and helps prevent breakdowns (on the old principle of 'a stitch in time...); (c) routine cleaning by the operator (rather than by the mainienance men after the machine has broken down) leads to a better understanding of the machine by the operator, and to earlier recognition of malfunctioning ("unusual noise when switched on').

Some firms experienced 'labour-relations' difficulties on introducing new machinery. in one plant in our British sample it took thirteen years to secure agreement to halve the manning on new equipment, installed in the early 1970s, to the levels for which the machinery was designed. Part of the remedy, at least, must lie in promoling a greater understanding of technological matiers amongst operators, leading in tum to less fear of inability to master new machinery, and hence to a greater desire to master it.

Greater competence would also eliminate the imcompetent tinkering by operators with their machinery that we were told of in a number of plants; hoping to increase ouiput bonuses, they made mechanical adjustments-which resulted in more frequent breakdowns.

\section{The qualiy of raw materals}

We asked firms in both countries about the quality of their raw material supplies to learn whether these might be a source of lower productivity (quite small variations in dimensions or hardness can cause excessive wear in tools, leading to high reject rates and breakdowns). Automated production requires much closer control of material specifications and tolerances, since the human operator is not there to adjust for variations; all too often in British plants we have seen recently automated machinery in which an operator has been assigned to 'help' the automalic feed because, tor example, 'today's baich of steel does not seem to be of the right temper'. In asking about the quality of materials we were also interested to know whether the deficiencies in skills and machinery detected in our sampled products affected their supplies in a similar way.

Two of the three English firms manufacturing screws told us they had experienced 'delivery problems' in their supplies of special steels; a German firm manufacturing springs said they had ceased using an English steel supplier because the supplies were not in accordance with specifications. In the purchase of non-ferrous castings, one firm had tried three British foundries and found their quality unacceptable (they were now importing them); another firm could not find a supplier to make a complex casting to the required standard, and they were now attemping to make their own-but with difficulties; a third firm experienced an astonishing scrap rate in its home-made castings. In the case of this last product, the matched German plant admitted that castings were often difficult and had high reject rates: but the German reject rate was only a tenth that in the British firm. The German firm emphasised the importance both of craft skills and of modem equipment in ensuring low reject rates in castings. The manager of one of the English firms buying castings made the same point. The qualify controller in another English firm put the blame on his firm for buying 'cheap' casings; by the time they had been sorted and 'bodged up' to specification he thought they had become very expensive (presumably, again, a lack of iechnical undersianding in the buying department; the Germans provide a specific training course in industrial purchasing-an occupation which has received only rudimentary recognition so far in this country).

Of course, every firm makes mistakes from time to time in buying as in other things, and if would be wrong to exaggerate the above instances. Most of the British firms we visited thought that in general raw materials presented litte problem. But one is bound 
to wonder: all too often firms continue to work with long-standing suppliers, and until they iry a competitor they do not know 'what they have been missing'.

The German firms that we visited often emphasised the reed for care in 'sourcing' their materials; they willingly paid a premium to ensure a qualitystandard suitable for their particular requirements. This kind of comment, based on a serious expertise in their paricular field, was not heard in the UK.

\section{Implications and summary}

To those familiar with earlier studies of productivity in the UK, especially the extensive series by the AngloAmerican Council on Productivity in the early 1950 s, the kind of inefficiencies mentioned here will not come entirely as a surprise. ${ }^{11}$ But it is worth noticing that a generation later we find it necessary to compare the performance of UK manufacturing no longer with the United States- with its immense home market and other special circumstances - but with a European country with a population comparable to that of the UK, similar geographical area and broadly similar natural resources, ${ }^{(2)}$ and which now has achieved a substanially higher level of manufacturing producivity.

Let us assume in this section that any further inquiry - with a larger sample of firms in Britain and Germany and a more detailed questionnaire-would confirm our findings more or less as presented above. What then would follow for policy in relation to: modern machinery, training and education at various levels, and further research? These are large questions; only a few general remarks can be offered here.

Perhaps the most important overall implication of this study is that lack of technical expertise and training, rather than a simple lack or modem machinery, is the stumbling block. We have seen that producers in the metal-working trades in this country have reconciled themselves to not being able to buy suitable British machinery. They require up-to-date machinery, and buy it on the world market-despite difficulites in dealing at long distance. The problem of British machine tool producers in designing, producing and servicing up-to-date machines can be seen as extended manifestations of the same skill-deficiencies noted in the present study of simple pro-

(1)Forty-seven sets of visits in the UK and US were carred out uncer the auspices of the Council; the reports most relevant to the presen inquiry were on Pressed Metal (1950), Valves (1950), Brass Foundry (1953), and Metakorking Machine Tools (1953). (2) Some argue that North Sea oil has led to a decline in the outout of British manutacturing. Withou going into the detailed economic mechanism whereby changes in comparative advantage affect the whole structure of industry. it will pernaps be agreed that there is no reason why productivity in manufacturing should be adversely affected by the discovery of oil (on the contrary, the eliminafion of marginal manufacturers should raise productivity). ducts, though probably with a greater emphasis on deficiencies of higher-level skills; bui the UK machine tool industry has not been at the centre of the present study, and represents only a small fraction of the metal-working industries. If the real problem in the latter is a lack of expertise and skills, doubt is cast on the wisdom of providing special subsidies to purchasers of machines, even of advanced technology; the money might be better spent on sending more personnel on training courses (perhaps also abroad). Doubt is of course also cast on the wisdom of excluding (or 'restraining') imports of advanced modern machinery.

Although there was a relative lack of NC machinery in the British plants in our sample, in our judgement the greater part of the productivity gap came from other sources: a lack of feeding devices, frequent machine breakdowns, poor maintenance procedures, inadequate control of the quality of raw materials, and similar deficiencies in basic production techniques. It would be a mistake on this perspective for public policy to emphasise 'high technology' at the expense of improving more basic production techniques. A similar view emerged from a recent examination of the production of a more complex product-home laundry machines in the UK; if pointed to the 'dangers of perceiving the need for technical change too exclusiyely as a matter of introducing information technology' (the author noted the potential of techniques, fairly well established in other branches, such as the use of pre-painted steel to reduce final finishing cosis, and of plastics moulded parts to replace complex metal assem-

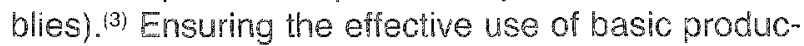
tion techniques is the role of the production engineer: our impression was that training in production engineering techniques (as distinct from what is usually covered in mechanical and electrical engineering courses) needs to be given considerably more emphasis in all engineering courses. This point is no doubt implicit in the Finniston report, but does not feature in is recommendations.

The formation of an Engineering Council, and greater utilisation of protessional engineers, were the central recommendations of the Finniston Report. Whether those recommendations per se can have any substantial effect or not (and we have our doubts), the present study supports the need for more engineering skills at the lop levels of a firm-io be concerned with product design, marketing strategy and engineering standards; it will, however, be clear that our report points to overwhelming deficiencies at lower levels.

(3)Peter Senker, Siraiegy, Technology and Skilis: A Report on the UK Home Laundry Appliances industry (Engineering Industry Training Board, 1984); pp.i, 24.6 . 
Looking at government policies directed towards that part of the skill specirum, does the Youth Training Scheme (YTS) perhaps provide a remedy? The lack so far of any examinable standards to be worked to under that scheme must limit its value in raising the technological capability of the workforce. It would be unrealistic to expect too much in the early years of what inevitably must be an extended and very heavy programme. When YTS is combined, as it will be in the next few years, with the benefits of an increased technological element in schooling (through the Technical and Vocational Education Initiative), it may well serve to raise the proficiency of the unskilled section of the labour force to an adequate level; but much more will be necessary if at least some proportion of the workforce is to be raised to the higher skill standards implicit in the German vocational scheme.

The major gap that we saw related to the technological capabilities of those of foreman or chargehand status, where the German level of competence was far ahead. The foreman in Britain is typically appointed for his managerial or human skills; the German foreman is primarily a technically qualified person who in addition has acquired further experience and the requisite managerial qualifications. The soundness of that combination much impressed members of a NEDO working party concerned with toolmaking when they compared British and German toolmaking plants; (1) because of the higher level of technical skils necessary in that trade, this may not seem surprising. But is it necessary in the ordinary run of production in metal-working and other trades? The lesson of the present study is that to organise production efficiently, and to produce goods that are preferred for their quality, a technically qualified foreman was highly desirable. We formed the view that there was a need for a strong policy initiative in this country in relation to the appropriate training, qualifications and incentives for foremen. A start is being made in that direction by one section of our engineering industry (gauge and tool manufacturing) based on the German model; ;(2) we believe that this approach needs ultimately to be widened to cover the whole of productive employment.

Just as worrying is the trend in general cratt training in this country. As we saw, the broad net of craft training in Germany has provided a basis for the rapid mastery of modern 'high technology' skills. In

\footnotetext{
(1)NEDO, Toolmaking (op. cit.), p.viii: 'The fundamental reason for this better performance (by the Germans) is the way... they achieve areater co-ordination, better use of equipmenl and tighter detailed control with relatively smaller overheads. The role played by the Meisters in Mest Germany is a key part of this approach and merits very careful study by British companies'.

(2) A scheme is under discussion at the time of writing for joint cerlification by the Engineering Industries Training Board (EITB) and the City and Guilds of Londion Institute following a 2-3 year scheme of education and training.
}

this country, craft and technician trainees in the engineering industries - under the supervision of the Engineering Industries Training Board-have fallen drastically from 28,000 in the first year of training in 1967 to 9,000 in 1983 ; more worrying, in a re-assessment of the Board's training priorities published in 1984 , the view was accepted that it should no longer 'seek to augment the industry's intake of craft or technician trainees. (3) This seems very puzzling to anyone taking a long view of the future of British manufacturing. No doubt a number of pressing reasons can be advanced for such a view; for example, that there are no jobs immediately available for those who have completed their training, or that the financial arrangements for trainees are unsatisfactory, or that the present syllabus for craftsman training is focused too little on newer skills and needs to be reformed. Such matters need fuller consideration than possible within the scope of this article; but we feel obliged to say, on the basis of what we have learnt from this study, that the gap at intermediate skill levels beween Britain and Gemany is very serious, and it seems likely to grow on present policies.

Finally, on matters of research: we have become convinced that the health of much of British manufacfuring industry remains precarious. Much is at stake. Expensive as interview studies of the present kind are, we found that the comparative perspective provided by this pilot study aroused much interest wherever we discussed our findings. Economists who research in general terms-treating labour as a single homogeneous commodity, and capital likewise - will not be able to assist in resolving the present very serious problems of British manufacturing industry; engineers alone we fear are sometimes too close to the excitement of advanced technological developments to see the economic importance of more mundare matters of basic productive efficiency. We hope therefore that those who control the purse strings of research will see fit to encourage more comparative empirical research of the kind reported here.

In Summary: Our concern in this paper has been with the determinants of productivity in two advanced industrial countries. Is it machinery or workforce skills that are more important? On the basis of interviews with management and factory floor employees at 45 matched firms in Britain and West Germany (mainly manufacturing simple metal products), the centrality of skills at all levels seemed apparent. British machinery was by no means older than that found in German plants, but more ofien than in

(3)EITB, Information Paper 72, Report of Consultations and a Programme for Consiructive Retorm (April 1984), p.2 (para 7.6). 
Cermany it lacked ancillary feeding devices, proper maintenance, and advanced numerical control devices. Breakdowns were more frequent, and took longer to put right.

For lack of suitable home-produced specialised machinery, a greater proportion of recently installed machinery was imported in Britain than in Germany. Especially on technologically advanced machinery, this led more often in Britain to delays on repairs following breakdowns because of difficulites in dealing with suppliers at long distance. There is no easy way of overcoming these problems; 10 reduce imports of such machinery by persuading foreign pro. ducers not to sell here can only reduce the efficiency of the metal-working industry. Where British firms were using less advanced machinery, or were installing advanced machinery with undue delay, the problem usually lay in a lack of technically qualified management.

The fault for poor maintenance, poor production control, and poor diagnosis of faults, has its origins in technical skills at the level of foremen and operators. The German unskilled operator look greater care of his machinery than in Britain, by cleaning away swarf and the like; these kinds of basic skills could be learnt with advantage on YTS courses.

The greatest contrast we found was between the technical qualifications of foremen: in Germany almosi all those we saw had taken advanced courses beyond that of crafisman level, whereas in England only a minority of foremen had attained even a crafts. mar's qualification. We were impressed-as was an earlier NEDO team concemed with toolmaking- with the great advanlages to productive efficiency of com- bining in one person technical and managerial skills. A broad policy initiative in that direction seems necessary.

\section{Acknowledgements}

We are, above all, grateful to the many firms which co-operated in this survey; without their help the present article could not have been written. We also received much helpful advice from the Institution of Production Engineers, especially Mr R. S. Pratt; from $M T$ T. Brady at the Science Policy Research Unit at Sussex University and from the Technical Change Centre, the Technical Policy Unit at Aston University, the Centre for Urban and Regional Development Studies at Newcastle, the Manpower Services Commission, NEDO, the Department of Employment and the London Business School. In Germany we benefited from discussion with Professor H. J. Ewers of the Technical University, Berlin; and with Dr. A. Sorge of the International Institute of Management in Berlin. The research was supported by a grant from the ESRC Panel on the Economics of Industry and Public Enterprise and by a supplementary travel grant from the Manpower Services Commission; the work forms part of the research programme of the Centre in Comparative Industrial Structure and Effciency (under S. J. Prais), sponsored by the ESRC at the National institute. We are grateful to $S$. J. Prais for help in planning the inquiry and for suggestions on the final form of the report; we are also grateful to colleagues at the Institute for helpful comments throughout the inquiry and on an earlier draft of this report. 